\section{Kesepadanan Penerjemahan Iklan Kecantikan dalam Brosur Travel in Style}

Faridatun Nida

Fakultas IImu Budaya, Universitas Gadjah Mada Surel: faridatun.nida@ugm.mail.ac.id

\title{
INTISARI
}

Kesepadanan penting untuk dicapai dalam terjemahan teks vokatif. Pengujian terhadap kesepadanan dapat dilakukan melalui analisis terhadap teknik yang diterapkan dalam terjemahannya. Menggunakan teori teknik terjemahan dari Molina-Albir, Newmark serta Vinay-Darbelnet, penelitian ini akan menguji kesepadanan pada terjemahan teks vokatif. Teks tersebut bersumber dari dua brosur iklan kecantikan dengan judul yang sama yaitu Travel in Style, masing-masing versi bahasa Indonesia dan bahasa Inggris. Data diambil melalui metode simak dengan teknik sadap dan catat. Setelah diklasifikasikan berdasarkan tekniknya, data selanjutnya dianalisis menggunakan metode deskriptif komparatif. Hasil analisis menunjukan bahwa kesepadanan dapat tercapai melalui beberapa teknik. Teknik - teknik tersebut menjadikan terjemahannya mengalami penyesuaian pada makna dan gaya bahasa teks sasaran. Penyesuaian dilakukan dengan pergeseran struktur, perubahan sudut pandang, implisitasi dan eksplisitasi terhadap informasi didalamnya, serta terjemahan bebas dengan tetap memperhatikan kata kunci dan efek stilistikanya.

Kata kunci: kesepadanan, penerjemahan, teks vokatif, teknik terjemahan.

\section{PENDAHULUAN}

Penerjemahan dipandang sebagai suatu usaha pengalihan pesan dari suatu simbol ke simbol yang lain. Hal tersebut dinyatakan oleh Larson (1984:3) serta Dosert dalam Catford (1965:35). Pengalihan pesan ini tidak hanya berfokus pada makna secara tekstual maupun kontekstual, tetapi juga pada gaya bahasanya (Nababan, 2008; Nida dan Taber, 1982). Mengingat usahanya sebagai pengalihan, maka hal yang dialihkan haruslah sepadan. Dengan kata lain, pesan yang ada pada teks sumber harus tersampaikan dengan makna dan gaya yang sepadan pada bahasa sasaran. Hal ini mengacu pada pernyataan Nida (1982:1) mengenai fokus terbaru dari kegiatan penerjemahan dalam tujuannya mencapai kesepadanan.

Kesepadanan merupakan hal yang penting dalam kegiatan penerjemahan, terutama pada terjemahan teks-teks persuasif. Teks jenis ini mengandung fungsi vokatif. Buhler dalam Newmark (1988:12) mendefinisikan istilah 'vokatif' dengan merujuk pada fungsi bahasa yaitu untuk membuat seseorang berpikir, bertindak dan bereaksi seperti apa yang diharapkan oleh teks tersebut. Fungsi ini banyak ditemukan pada teks-teks di dalam buku panduan dan iklan. 
Iklan merupakan suatu proses komunikasi yang bertujuan untuk membujuk atau menggiring orang untuk mengambil tindakan yang menguntungkan bagi pihak pembuat iklan (Durianto, dkk. dalam Kusrianti 2004:1). Penerjemahan pada iklan semakin sering dilakukan terkait dengan adanya kegiatan perdagangan global. Seperti dilansir pada laman PakarKomunikasi.com, penggunaan bahasa Internasional dan penyediaan fasilitas berupa teks terjemahan merupakan dua dari delapan strategi komunikasi pemasaran global.

Brosur Travel in Style menjadi sarana periklanan yang diterbitkan oleh Wardah Cosmetics untuk mencapai visinya, yaitu memperdagangkan produknya secara global. Dalam usahanya mencapai visi tersebut, brosur Travel in Style diterjemahkan ke dalam bahasa Inggris. Bahasa Inggris dianggap sebagai bahasa yang sudah tersebar luas dan lazim digunakan dalam perdagangan di seluruh dunia (Forrest dalam Jurisic, 1998:19).

Mengingat pernyataan Nida mengenai fokus terjemahan, yaitu mencapai kesepadanan, dan pernyataan Newmark mengenai pentingnya kesepadanan dalam suatu teks vokatif, maka penelitian ini akan membahas mengenai kesepadanan yang dicapai oleh teks yang tertulis dalam brosur Travel in Style. Kesepadanan ini dapat diuji melalui analisis terhadap teknik terjemahannya. Molina dan Albir (2002:509) mengatakan bahwa teknik terjemahan merupakan suatu prosedur untuk menganalisa dan mengklasifikasikan kesepadanan pada suatu terjemahan. Teori mengenai teknik terjemahan dari Molina dan Albir juga akan digunakan dalam analisis penelitian ini. Teori lainnya yaitu teori tentang jenis transposisi dari Newmark serta teori modulasi dari Vinay dan Darbelnet.

Penelitian mengenai terjemahan dalam periklanan telah dilakukan sebelumnya oleh Jurisic (1998) dan Tuna (2004). Dengan berfokus pada teknik terjemahan, Lusi (2010) melakukan penelitian dengan data berupa buku petunjuk penggunaan produk kosmetik, sedangkan Wenny (2013) menggunakan data dari brosur pariwisata. Penelitian terbaru dilakukan oleh Zheng (2018) terhadap strategi terjemahan yang dikaitkan dengan budaya bahasa sumber dan bahasa sasarannya.

Penelitian ini memiliki fokus yang berbeda dengan penelitian sebelumnya. Pengumpulan data dilakukan dengan menggunakan metode simak serta teknik sadap dan catat. Kemudian, analisis dilakukan menggunakan metode deskriptif komparatif. Dengan mendeskripsikan data pada masing-masing teks dan membandingkannya, maka akan diketahui teknik-teknik yang digunakan dalam terjemahannya. Hal ini sejalan dengan tujuan penelitian yaitu untuk mengetahui kesepadanan yang tercapai melalui teknik terjemahannya.

Pencapaian kesepadanan seperti terjemahan di atas nyatanya tidaklah mudah. Kesepadanan ini menjadi salah satu permasalahan yang sering dihadapi dalam suatu terjemahan (Catford, 
1965:21). Penelitian ini akan membahas mengenai teknik-teknik yang dapat diterapkan untuk mencapai kesepadanan. Penemuan dalam penelitian ini diharapkan mampu memberikan solusi mengenai permasalahan dalam terjemahan, khususnya kesepadanan, melalui analisis terhadap teknik yang diterapkannya.

\section{HASIL DAN PEMBAHASAN}

Penilaian terhadap kesepadanan dilakukan melalui analisis teknik terjemahannya. Berdasarkan analisis terhadap data yang telah terkumpul, terdapat beberapa variasi teknik terjemahan yang terlibat dalam terjemahan brosur iklan kecantikan Travel in Style. Variasi tersebut berupa teknik tunggal (terjemahan dengan satu teknik), teknik kuplet (terjemahan dengan dua teknik) dan teknik triplet (terjemahan dengan tiga teknik).

\section{Teknik Tunggal}

Teknik tunggal mengacu pada satu teknik tertentu yang digunakan dalam terjemahan suatu data. Ditemukan beberapa macam teknik tunggal yang diterapkan guna mencapai kesepadanan. Teknik-teknik tersebut adalah teknik transposisi, modulasi, terjemahan literal, kalke, kesepadanan lazim dan kompresi linguistik.

\section{a. Transposisi}

Teknik tunggal yang paling sering ditemukan adalah teknik transposisi. Teknik ini menjadikan hasil terjemahannya mengalami pergeseran. Pergeseran terjadi bervariasi, seperti pergeseran posisi adjektiva, pergeseran dari frasa ke kata dan pergeseran dari tunggal ke jamak.

(1) TSu: Penampilan yang cantik dan menarik akan membangun kepercayaan diri.

TSa: A captivating and beautiful look will build up confidence.

Kesepadanan dapat tercapai dengan menerapkan teknik transposisi seperti data (1). Transposisi yang terjadi adalah transposisi berupa pergeseran posisi adjektiva yang mengakibatkan perubahan struktur gramatikal frasanya. Pada teks sumber, adjektiva berupa cantik dan menarik terletak di sebelah kanan atau setelah nomina yang diterangkannya. Sebaliknya, pada teks sasaran, terjemahan kedua adjektiva tersebut berada di sebelah kiri atau sebelum nomina yang diterangkannya. Perubahan ini terjadi secara otomatis. Tidak ada pilihan lain selain menerjemahkan dengan cara demikian. Perubahan dimaksudkan untuk menyesuaikan dengan struktur tata bahasa yang berlaku pada bahasa sasaran. Perubahan ini tidak mengganggu kesepadan maknanya dikarenakan kedua adjektiva pada bahasa sumber diterjemahkan secara literal dengan memilih padanan kata yang sesuai dalam bahasa sasaran. Kata cantik dalam bahasa sumber sepadan maknanya dengan kata beautiful dalam 
bahasa sasaran. Kata menarik dalam bahasa sumber sepadan maknanya dengan kata captivating dalam bahasa sasaran.

Transposisi berupa perubahan posisi adjektiva juga dapat terjadi bersama dengan transposisi dari tunggal ke jamak guna mencapai kesepadanan maknanya.

(2) TSu: Berhati-hatilah dengan bibir yang kering, bawalah selalu Wardah Lipgloss di saku Anda.

TSa: Be careful with dry lips, always carry Wardah Lipgloss in your pocket.

Transposisi adjektiva ditunjukkan oleh kata kering dan terjemahannya yaitu dry. Transposisi jenis tunggal ke jamak ditunjukkan oleh nominanya yaitu bibir yang diterjemahkan menjadi lips. Kata bibir dalam bahasa sumber merupakan bentuk tunggal, merujuk pada sepasang bibir yaitu bibir atas dan bibir bawah. Pandangan ini berbeda dengan bahasa sasaran. Pada bahasa sasaran, bibir dihitung sebagai nomina satuan. Kata lip merupakan bentuk tunggal dari bibir yang mengacu hanya pada satu bagian saja, bibir atas atau bibir bawah. Pada bahasa sasaran, sepasang bibir dianggap terdiri dari dua bibir. Diperlukan bentuk jamak yaitu lips untuk mengacu pada sepasang bibir. Seperti terlihat pada (2), lips menjadi terjemahan dari bibir. Lips merupakan bentuk jamak. Hal ini dikarenakan pelekatan imbuhan suffix -s/-es dibelakang suatu kata dapat menjadinya bermakna jamak (Katamba, 1993; Bache, 2000; Spectrum, 2007).

Meskipun bahasa sumber memiliki bentuk jamak berupa pengulangan kata dasar, namun hal ini tidak lazim diterapkan pada kata bibir. Berbeda dengan bahasa sasaran yang selalu memperhatikan bentuk jamak dan tunggalnya. Pemahaman terhadap makna teks sumber dan konteks yang menyertainya, menjadikan terjemahan tersebut dikatakan sepadan.

Dari penjabaran kasus-kasus di atas, kesepadanan dapat tercapai dengan menerapkan teknik transposisi seperti perubahan dari tunggal ke jamak serta perubahan pada posisi adjektiva. Perubahan-perubahan tersebut terjadi karena penyesuaian makna dalam konteksnya dengan kaidah tata gramatikal bahasa sasaran.

\section{b. Modulasi}

Modulasi merupakan teknik yang mengubah suatu kata atau kalimat pada teks sumber dari segi sudut pandang, baik secara struktural maupun leksikal. Modulasi juga diterapkan dengan mengubah perspektif, fokus maupun kategori kognitifnya. Teknik ini dapat diterapkan untuk mencapai kesepadanan pada terjemahannya.

(3) TSu: Sudah siapkah Anda berlibur?

TSa: Are you ready to go? 
Pada data (3) terlihat adanya penerapan modulasi baik secara struktural maupun leksikal. Perubahan secara struktural terlihat susunan bentuk kalimat interogatifnya. Perubahan secara struktural ini dilakukan guna mengikuti kaidah tata bahasa baku yang berlaku pada bahasa sasaran. Dalam bahasa sumber, sebuah adjektiva diperbolehkan menempati posisi sebagai kata tanya dengan penanda tanya berupa klitika - $k a h$. Hal yang sama tidak dapat terjadi pada bahasa sasaran. Dalam bahasa sasaran, terdapat struktur baku yang menandai kalimat tanya jenis Yes/No question, yaitu to be. Dalam hal ini, to be ditunjukkan oleh kata are, yang diikuti oleh subjek dan adjektiva. Seperti terlihat pada terjemahannya, kata ready yang merupakan terjemahan dari siap, mengalami perubahan posisi yaitu terletak setelah subjek you.

Perubahan secara leksikal dapat diketahui melalui perubahan maknanya secara literal meski posisinya cenderung tetap. Hal ini terlihat pada kata berlibur yang diterjemahkan menjadi go. Dalam bahasa sasaran, kata dasar libur memiliki padanan kata dengan holiday atau vacation, namun kata-kata tersebut tidak lazim digunakan sebagai verba. Dengan mempertimbangkan kognisi pembaca bahasa sasaran, maka verba berlibur diubah menjadi go. Dalam bahasa sasaran, go berarti pergi. Perubahan ini tidak menyebabkan terjemahannya menjadi tidak sepadan. Hasil terjemahan tersebut tetap dikatakan sepadan.

Kasus seperti pada (3) menunjukan bahwa kesepadanan dapat tercapai melalui teknik modulasi. Teknik tersebut mengakibatkan perubahan sudut pandang secara struktural mengikuti kaidah tata kalimat pada teks sasaran. Pemilihan leksikal juga disesuaikan oleh kelaziman pemakaiannya pada bahasa sasaran.

\section{c. Terjemahan literal}

Terjemahan literal merupakan teknik menerjemahkan dengan mencari padanan leksikal pada setiap katanya melalui pemaknaan secara literal tanpa disertai perubahan urutan katanya. Penerapan terjemahan ini juga terjadi tanpa disertai perubahan struktur.

(4) TSu: Sekarang kita siap untuk berangkat.

TSa: Now we're ready to go.

Terjemahan literal diterapkan pada kalimat (4). Setiap kata diterjemahkan secara literal. Struktur kalimat pada teks sumbernya sesuai dengan struktur kalimat pada bahasa sasaran sehingga teks sumber tersebut dapat diterjemahkan tanpa mengalami pergeseran struktur. Masing-masing kata pada bahasa sumber memiliki padanannya pada bahasa sasaran. Kemudian, baik dalam bahasa sumber maupun bahasa sasaran, adjektiva diperbolehkan menempati posisi sebelum subjek suatu kalimat deklaratif. Oleh karenanya, sekarang yang secara literal sepadan dengan now tetap dapat diletakkan di awal kalimat pada teks sasaran (Quirk, 1985:49). Kalimat deklaratif pada kedua bahasa juga memiliki struktur yang sama yaitu 
subjek yang diikuti oleh predikat. Tidak adanya perubahan secara struktural dan leksikal menunjukkan diterapkannya teknik terjemahan literal dan tercapainya kesepadanan makna pada teks terjemahan terhadap teks sumbernya.

Melalui kasus di atas, disimpulkan bahwa kesepadanan dapat tercipta melalui teknik terjemahan literal jika teks sumber memiliki struktur yang sama dan kata yang maknanya sepadan dengan teks bahasa sasaran.

\section{d. Kalke}

Kalke diterapkan pada penerjemahan suatu istilah secara literal. Penerjemahan ini dapat menyebabkan adanya inversi, baik secara leksikal maupun struktural seperti terlihat pada data berikut.

\section{(5) TSu: Sabun cair}

\section{TSa: Liquid soap}

Dengan teknik kalke, frasa sabun cair diterjemahkan secara literal dengan inversi struktural menjadi liquid soap. Liquid merupakan terjemahan secara literal dari kata cair dan soap merupakan terjemahan secara literal dari kata sabun. Inversi struktural terjadi secara otomatis mengikuti kaidah bahasa sasaran dimana posisi adjektiva berada sebelum nomina yang diterangkannya.

Kesepadanan yang dapat tercapai dengan teknik kalke umumnya berbentuk frasa. Terjemahan dilakukan secara literal dengan penyesuaian struktur pada teks sasarannya.

\section{e. Kesepadanan lazim}

Kesepadanan lazim umumnya diterapkan pada tataran kata dan frasa. Terjemahan ini dapat dilakukan dengan bantuan kamus.

(6) TSu: Siang hari

TSa: Day Time

Frasa di atas diketahui menggunakan terjemahan kesepadanan lazim dalam mencapai kesepadanan maknanya. Masing-masing kata pada teks sumber tidak diterjemahkan secara literal, namun istilah tersebut lazim digunakan pada bahasa sasaran. Terjemahan tersebut juga dapat ditemukan dalam kamus kedua bahasa. Siang hari sepadan maknanya dengan kata day time (Echols dan Shadily, 2008). Kedua bahasa memiliki konsep yang sama tentang siang hari dan daytime. Selain itu, keduanya juga merujuk pada hal yang sama yaitu suatu periode waktu saat langit cerah seiring dengan adanya matahari dan saat langit belum gelap seiring dengan adanya bulan. Kesamaan makna pada keduanya dan kelaziman frasa tersebut dalam 
penggunaannya oleh pengguna masing-masing bahasa menjadikan hasil terjemahan tersebut dianggap sepadan dengan teks sumbernya.

Penerjemahan teknik ini paling mudah dalam mencapai kesepadanan karena kata terjemahannya tersedia dalam kamus atau dalam otak penutur bahasanya.

\section{f. Reduksi}

Terjemahan dengan melesapkan informasi diindikasikan menggunakan teknik reduksi. Penerapan terhadap teknik ini dapat memberikan peluang pada hasil terjemahannya untuk mencapai kesepadanan.

(7) TSu: Karena perjalanan traveling adalah kebahagiaan dan inspirasi. TSa: Because travelling is happiness and inspiration

Kata perjalanan yang terdapat pada teks sumbernya dihilangkan pada terjemahannya. Penghilangan ini dilakukan untuk menghindari kelebihan informasi mengingat kata yang bersanding di sampingnya adalah kata travelling. Kata tersebut juga bermakna perjalanan. Digunakannya istilah asing pada teks sumber dikarenakan familiaritas pembaca terhadap kata asing tersebut. Anggapan keakraban pembaca terhadap kata travelling juga berkaitan dengan judul pada brosur yaitu Travel in Style. Kata travelling memiliki makna yaitu melakukan suatu perjalanan. Dengan makna yang terkandung didalamnya, maka makna dari kata perjalanan sudah termasuk didalamnya. Hal ini menyebabkan kata perjalanan dapat dihilangkan dalam terjemahannya. Penerapan teknik kompresi semacam ini tidak mengubah makna, sehingga membuat terjemahan pada (7) mencapai kesepadanan.

Kesepadanan tetap tercapai karena terdapat kata travelling yang maknanya sudah mewakili makna dari perjalanan itu sendiri. Dapat dikatakan bahwa makna dari perjalanan tidak hilang melainkan dilesapkan pada kata yang lain yang memiliki makna yang sama. Pelesapan menjadikan kalimat dalam wacana tersebut menjadi lebih efektif dan efisien (Kusrianti, 2004).

\section{g. Kompensasi}

Penerapan teknik kompensasi pada penerjemahan suatu data dapat membantu tercapainya kesepadanan.

(8) TSu: Ingatlah bahwa berlibur adalah meluangkan waktu bagi diri sendiri.

TSa: Remember that holiday is an exclusive time spent for you and only you.

Diri sendiri pada teks sumber diindikasikan mengandung suatu stalistika berupa penekanan terhadap kata diri dan sendiri. Hal ini merujuk pada hasil terjemahannya yang mengulang kata you. Dalam bahasa sasaran, terdapat padanan secara literal untuk diri sendiri yaitu yourself. Namun, stilistika yang ada dalam teks sumber kurang tersampaikan jika hanya diterjemahkan 
secara literal. Kompensasi dilibatkan dalam terjemahan ini untuk menghasilkan efek yang sama dengan teks sumbernya sehingga menghasilkan terjemahan yaitu you and only you. Kesan dalam teks sumber mengenai betapa pentingnya waktu liburan bagi diri sendiri tersampaikan pada teks sasaran.

Penerjemahan perlu memperhatikan stilistika. Dengan teknik kompensasi, penerjemahan melibatkan pengalihan efek stilistika yang terdapat pada teks sumbernya sehingga dapat menjadikan suatu hasil terjemahan mencapai kesepadanan makna dengan kesan yang sepadan pula.

\section{h. Kreasi diskursif}

Penerjemahan menggunakan kreasi diskursif juga dapat membuat suatu terjemahan mencapai kesepadanan meski kata-kata pada teks terjemahannya cenderung berubah.

\section{(9) TSu: Yuk, bergaya cantik saat Liburan!}

\section{TSa: Gals, Let's Be the Holiday Queen!}

Kesepadanan tercipta karena tetap hadirnya kata kunci yang menjadikan pesan dari teks sumber dan teks sasaran mengandung informasi yang sama. Kata kuncinya terlihat pada kata Yuk yang dterjemahkan menjadi Let's dan kata liburan yang diterjemahkan menjadi Holiday. Selain itu terdapat satu kata pada teks sumber dan teks sasaran yang memiliki fitur semantik yang sama. Kata tersebut adalah cantik dan Queen. Queen diidentikkan dengan sifatnya yang cantik. Penggunaan kata Queen dinilai mencangkup pesan pada teks sumber yang berupa adjektiva cantik. Secara keseluruhan keduanya mengandung pesan yang sama, yaitu mengajak para pembaca untuk tetap memperhatikan penampilannya supaya tampil cantik.

Meskipun bersifat sementara, penerjemahan dengan melibatkan konteks dapat menciptakan suatu kesepadanan dengan memperhatikan kata kunci yang digunakan pada kedua teks tersebut.

\section{Teknik Kuplet}

Teknik kuplet yaitu dua teknik yang diterapkan pada suatu terjemahan. Terdapat data, umumnya berbentuk frasa, yang ditemukan menggunakan dua teknik sekaligus dalam terjemahannya. Variasi teknik kuplet yang ditemukan yaitu teknik transposisi dan amplifikasi linguistik, transposisi dan modulasi, kompresi linguistik dan transposisi, partikularisasi dan transposisi, serta transposisi dan partikularisasi. Kolaborasi dari kedua teknik tersebut menjadikan terjemaahannya mencapai kesepadanan. 


\section{a. Transposisi dan Amplifikasi}

Penerapan teknik kuplet yang terdiri dari transposisi dan amplifikasi dapat membantu suatu terjemahan dalam mencapai kesepadanan.

(10) TSu: Setelah kita mengenal cara mengemas makeup, mari kita belajar bagaimana mengatur isi koper yang baik.

TSa: After we have learned to pack our makeup tools cleverly, let's learn how to arrange our suitcase.

Teknik amplifikasi dan transposisi terlihat pada kata makeup yang diterjemahkan menjadi our makeup tools. Definisi makeup pada bahasa sumber adalah produk kosmetik yang berwarna sehingga bila digunakan pada tubuh atau bagian tubuh tertentu akan menghasilkan warna. Mengacu pada kamus Oxford, definisi makeup merujuk pada substansi yang membuat wajah seseorang menjadi lebih menarik. Melihat konteksnya, makeup pada teks sumber sudah dapat mencangkup alat kosmetik. Kata ini tidak dapat diterjemahkan secara harfiah pada teks sasaran. Hal ini dikarenakan definisi makeup pada bahasa sasaran yang tidak mengacu pada suatu alat melainkan pada substansi. Diperlukan adanya parafrase terhadap informasi dari teks sumbernya supaya terjemahannya terhadap kata makeup pada teks sasaran lebih mudah untuk dipahami. Melihat pada verbanya yaitu mengemas dan penyebutan berbagai macam kosmetik pada kalimat sebelumnya, maka kata makeup dapat ditambahkan kata tools. Tools berarti peralatan. Makeup tools berarti peralatan makeup. Kata ini lebih tepat untuk menyampaikan makna makeup yang ada pada konteks bahasa sumber. Dengan demikian, penambahan kata tools menyebabkan kata makeup mengalami perubahan bentuk dari kata menjadi frasa.

Melalui teknik transposisi dan amplifikasi, dapat ditarik kesimpulan bahwa pemaknaan terhadap kata yang diterjemahkan dapat menyebabkan kata tersebut memerlukan imbuhan kata lain atau eksplisitasi pada teks sasarannya untuk memproduksi makna yang sepadan dengan kata pada teks sumbernya.

\section{b. Transposisi dan Modulasi}

Penerapan teknik modulasi beserta transposisi didalamnya dapat membuat suatu terjemahan mencapai kesepadaan dengan teks sumbernya.

(11) TSu: Pisahkan menurut jadwal pemakaian baju-baju tersebut.

TSa: Define them by time of usage.

Transposisi pada data (11) yang terjadi bersama dengan modulasi berupa transposisi dari bentuk frasa nomina menjadi kata pronominal. Hal ini ditunjukkan oleh kata frasa baju - baju tersebut yang diterjemahkan menjadi them. Perubahan bentuk ini dilakukan untuk mempersingkat informasi yang terdapat dalam frasa tersebut. Dengan kata - kata yang sama, imformasi tersebut sudah disebutkan pada kalimat sebelumnya. Perubahan bentuk ini terjadi bersama 
dengan perubahan pada posisinya secara struktural kalimatnya. Pada bentuk kalimat imperatif bahasa sasaran diperlukan adanya objek setelah verbanya. Hal ini merupakan kaidah baku. Berbeda dengan teks sumber yang dapat menyusun kalimat imperatif dengan susunan verba yang diikuti langsung oleh adverbial manner. Kaidah ini menyebabkan kata them mengalami perubahan kedudukan pada data (11).

Penyesuaian terhadap struktur kalimat bahasa sasaran beserta perubahan bentuk frasanya guna menghindari pengulangan kata dapat menjadikan suatu teks terjemahan mencapai kesepadanan.

\section{c. Transposisi dan kompresi}

Selain transposisi dan modulasi, perpaduan dua teknik yaitu teknik transposisi dan kompresi juga dapat menyebabkan suatu hasil terjemahan mencapai kesepadanan.

(12) TSu: Aktivitas paling asik untuk meliburkan diri dari rutinitas pekerjaan dan meluangkan waktu bagi diri sendiri.

TSa: It is the most fun and exciting way to escape routines and have time for yourself.

Pelesapan nomina pekerjaan pada frasa rutinitas pekerjaan menyebabkan frasa tersebut mengalami perubahan bentuk menjadi kata tunggal. Pelesapan kata ini dilakukan karena pada teks sumber kata routine sudah mencakup aktivitas atau pekerjaan. Rutinitas dalam teks sumber bermakna sesuatu yang dilakukan secara teratur, termasuk didalamnya aktivitas. Begitu juga maknanya pada teks sasaran. Penghilangan ini tidak berpengaruh terhadap pencapaian kesepadanannya. Hasil terjemahan tetap dikatakan sepadan karena makna dari kata pekerjaan dalam teks sumber sudah tercakup dalam kata routines dalam teks sasaran. Dengan demikian, untuk kemudahan dalam pembacaan dan mencegah kekakuan dalam terjemahannya, kata pekerjaan dipertimbangkan lebih baik untuk dilesapkan.

\section{(13)TSu: la sadar kepuasan adalah tujuan pribadinya}

\section{TSa: She realizes fulfilment is her goal}

Dua teknik yaitu kompresi linguistik dan partikularisasi diterapkan pada terjemahan frasa tujuan pribadinya. Kompresi dilakukan terhadap nomina pribadi. Kata tersebut tidak diterjemahkan dengan tujuan untuk menyingkat informasi. Meskipun dimungkinkan, terjemahan kata pribadi secara literal akan membuat kalimat tersebut terkesan bertele-tele, kurang efisien dan tidak lugas. Selain itu, kata her dalam terjemahannya dapat dikatakan sudah mewakili makna dari kata pribadi yang bersanding dengan kata tujuan atau goal.

Meskipun menyebabkan perubahan bentuk, pelesapan terhadap suatu kata dapat dilakukan ketika kata yang bersanding dengannya sudah mengandung makna dari kata yang 
dihilangkannya. Kata yang dilesapkan terimplisitkan oleh kata yang lain sehingga makna dari kata tersebut pada suatu konteks data menjadi tidak hilang. Maknanya dapat terwakilkan oleh kata yang lain. Kesepadanan tetap dapat tercapai meski terjadi pelesapan dan perubahan bentuknya.

\section{Teknik Triplet}

Teknik triplet adalah tiga teknik yang dilibatkan dalam terjemahan suatu data. Hasil analisis menunjukan adanya beberapa variasi dari teknik triplet demi tujuannya mencapai kesepadanan. Variasi teknik triplet terlihat pada penjelasan di bawah ini.

\section{a. Modulasi, Transposisi dan Amplifikasi Linguistik}

Perubahan sudut pandang dapat disertai dengan perubahan pada beberapa satuan lingual untuk menyesuaikan dengan bahasa sasarannya, baik secara makna maupun strukturnya.

\section{(14)TSu: Apalagi menjadi keriput dan tidak elastis gara-gara UVA.}

TSa: While UVA will cause wrinkle and inelasticity to your skin.

Teknik yang pertama diterapkan adalah modulasi. Teknik tersebut mengubah fokus pada teks sasarannya. Pada teks sumber, fokus ditekankan pada akibat yang timbul yaitu kondisi kulit yang keriput dan tidak elastis. Pada teks sasaran, fokus informasinya ditekankan pada penyebabnya yaitu UVA. Dengan kata lain, penerapan teknik modulasi mengubah fokus kalimat tersebut dari akibat menjadi sebab. Perubahan sudut pandang ini tetap memperhatikan susunan gramatikal pada kalimatnya. Susunan gramatikal membutuhkan adanya tambahan satuan lingual berupa frasa your skin. Penambahan your skin pada data (15) dikarenakan perlunya objek sebagai pemilik adjektiva yang disebutkan yaitu keriput dan tidak elastis. Pada bahasa sumber, kedua adjektiva tersebut sudah mengacu pada kulit, tetap dapat berterima meskipun tidak disertai dengan penyebutan objeknya.

Selain terjadi penambahan, terjadi pula transposisi kelas kata dari adjektiva menjadi nomina. Hal ini terlihat pada kata tidak elastis yang diterjemahkan menjadi inelasticity. Menurut Jackson (2002:12), pelekatan suffix dapat menyebabkan terjadinya perubahan kelas kata pada kata yang dilekatkannya. Pada kasus ini, terjadi penambahan suffix berupa -ity pada kata inelastic mengubahnya dari adjektiva menjadi nomina. Perubahan semacam ini dimaksudkan untuk memudahkan dalam pembacaannya dan mempertimbangkan kelaziman dalam pemakaian kata tersebut dalam teks sasaran. Oleh karena itu, penambahan dan perubahan ini berkaitan dengan pertimbangan terhadap tingkat kognisi pembaca bahasa sasaran, seperti alasan diterapkannya teknik modulasi.

Perubahan sudut pandang tidak disertai dengan pergeseran makna. Modulasi hanya mengubah cara penyampaiannya. Demikian juga dengan penambahan frasa nomina yang bertujuan untuk 
mengeksplisitkan makna yang implisit dalam teks sumber. Dalam kasus ini, penerapan teknik modulasi, yang mengakibatkan adanya transposisi dan amplifikasi linguistik tidak mengurangi nilai kesepadanan.

\section{KESIMPULAN}

Pembahasan di atas menunjukan bahwa kesepadanan dapat dicapai melalui penerapan teknik terjemahannya. Teknik tersebut bervariasi, mulai dari teknik tunggal, teknik kuplet, hingga teknik triplet. Kesepadanan dapat dicapai jika kedua teks, teks sumber dan teks sasaran, memiliki kesamaan makna dan gaya bahasa. Kesamaan tersebut dapat tercipta dengan penyesuaiannya terhadap bahasa sasaran. Penyesuaian tersebut dilakukan dengan pergeseran gramatikal, perubahan sudut pandang sesuai dengan kognisi pembaca sasaran, pengalihan sesuai makna literalnya, dan pengalihan leksikal secara bebas dengan tetap memperhatikan kata kuncinya. Selain itu, dapat juga dilakukan melalui eksplisitasi hal yang implisit pada teks sumber dan sebaliknya, mengimplisitasi hal yang eksplisit pada teks sumber.

\section{DAFTAR PUSTAKA}

Bache, Carl. 2000. Essentials of Mastering English. Berlin: Walter de Guyter.

Echols, M. John dan Shadily, Hassan. 2008. Kamus Indonesia Inggris Edisi Ketiga. Jakarta: Gramedia.

Jackson, Howard. 2002. Lexicography: An Introduction. London: Routledge.

Katamba, Francis. 1993. Morphology. Australia: Macmillan.

Kusrianti, Ani., dkk. 2004. Analisis Wacana Iklan Lagu Puisi Cerpen Novel Drama. Bandung: Pakar Karya.

Lakoff, Robin. 1973. Language in Women's Place. Research Gate. DOI: 10.1017/Soo474045000 00051

Larson, Mildred L. 1984. Meaning-Based Translation. Oxford: University Press of America.

Molina, Lucia dan Albir, Emparo Hutardo. 2002. Translation Technique Revisited: A Dynamic and Functionalist Approach. Meta, 47(4), 498-512. doi: 10.7202/008033ar.

Nababan, M. R. 2008. Teori Menerjemah Bahasa Inggris. Yogyakarta: Pustaka Pelajar.

Newmark, Peter. 1988. A Textbook of Translation. New York: Prentice Hall.

Nida, Eugene A. dan Taber, Charles R. 1969. The Theory and Practice of Translation. Leiden: E. J. Brill

Spectrum. 2007. Language Arts, Grade 5. USA: School Specialty Publishing.

8 Strategi Komunikasi Perdagangan Global. PakarKomunikasi.com. Diambil dari https://pakar komunikasi.com/strategi-komunikasi-pemasaran-global pada 8 Agustus 2018. 